\title{
静電気による笑害発生とその対策
}

\author{
上月 三 郎*
}

\section{1． 静電気による災害危險}

\section{1-1. 静電気による火災}

消防庁の統計によると，静電気のスパーク放電少にる 火災は第1表に示すように.しだいに增加し，年間 100 件 以上に達している。

第 1 表 静電気による火㷋

\begin{tabular}{|c|c|c|c|}
\hline 年度別 区分 & $\begin{array}{l}\text { 総 火 災 } \\
\text { 件 数 }\end{array}$ & $\begin{array}{l}\text { 電気火狤 } \\
\text { 件 数 }\end{array}$ & $\begin{array}{l}\text { 静 電 気 } \\
\text { 火炎件数 }\end{array}$ \\
\hline 昭和 35 年 & 43,679 & 4,910 & 71 \\
\hline 36 & 47,106 & 5,858 & 78 \\
\hline 37 & 49,644 & 5,627 & 81 \\
\hline 38 & 50,478 & 6,011 & 91 \\
\hline 39 & 49,020 & 6,082 & 108 \\
\hline
\end{tabular}

\section{1-2．静電気による災害危険の調査結果}

当所では，昭和 40 年 9 月清雪電気迆苂害の発生 しそらな事業場を対象として，アンケートにより，その 実態を調查した。回答のあったのは 363 事業婸で, そ の主な結果は次のと㧍りである。

1-2-1. 過去（昭 37.1 40.8）における静電気災障 害の発生状況

\section{a. 電 擊}

静電気により作業者が電擎を受けたのは 194 事業場で 全事業場の $53.4 \%$ に達している。これを電撃のひん度 別に見ると
「まれに」
$68.6 \%$
「ときどきに」
$27.8 \%$
「ひんぱんに」
$3.6 \%$

な打電撃による大きな死傷災害はなかった。

b. 可燃性ガス蒸気への引火

静電気による放電火花で可燃性ガス・蒸気に着火した ことのある事業場は 50 で, 全事業場の $13.8 \%$ ，その らち，爆発または炏を生じたのが 24 事業場で $6.6 \%$ である。残りの 26 聚業場では引火したが大事に至ら社 かった。

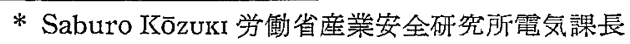
Electro Static Hazard and Its Prevention

\section{c. 可燃性粉じんへの着火}

ガス蒸気の場合に比べて, 粉じんへの着火の例は少な

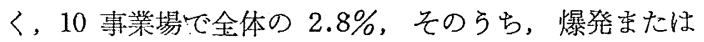
火㷋を生じたのが 5 事業場である。

な筝電気に上る放電火花を発生しているのが 121 事 業場で, 全事業場の $1 / 3$ であり, そのうちの $1 / 2$ が, ガ スまたは粉じんに着火している。しかも一事紫場で数回 ないし十数回も着火したことのある事業場も含まれてい る。

\section{d. 生産障害}

静電気により系や紙が互にくっつき合ったり，粉体が ふるいの目を通りにくいなど，生锖に障害のあった事業 場が 124 で全体の $34.2 \%$ ，作業者が静電気による電撃 を招それて生産能率に影響したのが 37 事業場で 10.2 \%である。したがって静電気注より生産になんらかの悪 影響を与えている事業場が全体の 44.4\%に達している。 しかもこの比率は化学纎維業では $79.3 \%$, 繊維工業で は $84.2 \%$ ，に達している。

\section{1-2-2． 静電気による災障害危険の現況}

\section{a. 現在における災障害危険の概況}

各事業場において現在静電気による災障害の危険があ るかどうかを調查した結果, 全危険が 486 件で 1 事業 場あたり 1.34 件に達している。全件数に対するる分布は 次のと拈りである。

電馨を受けることがある $33.9 \%$ ガス蒸気に着火乙，爆発火災の扣气れがある $20.2 \%$ 粉じんに着火し爆発火災の括それがある $5.6 \%$ 放電火花を発生するが懪発火災の拉それはない $11.5 \%$ 生産障害を生じ，その損害は大きい 生産障害を生ずるがその損害は小さい

\section{b. 最近 1 年間の災害危険発生ひん度}

最近 1 年間に，電揧を受けたり，放電火花に上り着火 したり，火災爆発を生じたのはあわせて何件ぐらいある かといらことを調查した結果，回答のあった 111 事業場 での内訳は次のごとくであった。
$1 \sim 2$ 件
$71.2 \%$
$3 \sim 5$ 件
$17.1 \%$
$6 \sim 10$ 件
$3.6 \%$ 
11 件以上 $8.1 \%$

\section{1-2-3. 静電気の発生工程}

前述のよらに静電気による災害危険があるが，これら の静電気がぞのような工程において発生しているかを調 查した結果は次のと预りで，発生工程の合計 592 亿対寸 る百分率で示したものである。

気体 $\cdot$ 液体 粉体の流送工程

$25.5 \%$

（気体一 4.2 , 液体一 -12.5 , 粉体一 8.8 )

気体・液体 $\cdot$ 粉体の噴出工程

$11.6 \%$

（気体一 4.7 , 液体一 4.5 , 粉体一 2.4 )

粉体の混合・かきまぜ・口過工程

（混合一 $6.3 ，$ かきまぜ一 $-3.9 ，$ 口過一 4.7 )

固体の粉砕・粉体の混合，らるい

（粉碎一 6.1 , 混合一 4.7 , らるい-6.6)

液状物の練り

$2.4 \%$

液状物の塗布

$5.2 \%$

固体のはく離

$7.8 \%$

その他の工程

$15.2 \%$

\section{1-2-4. 静電気の帯電部分}

静電気により带電する部分を調查した結果は次のとお

りで，全数 552 に対する百分率で示したものである。

パイプなどの流送部分

$16.3 \%$

ロール機などの粉碎・練りの装置

$8.7 \%$

ベルトなどの動力伝導装置

$12.0 \%$

ふるいまたは口過装置

$8.7 \%$

その他の機械装置

$12.2 \%$

加工中の原材料

$14.1 \%$

でき上った製品または半製品

$20.6 \%$

その他

$7.4 \%$

\section{1-2-5． 静電気による災害事例}

前記調查において，各事業場において昭和 37 年 1 月 より昭和 40 年 8 月字で発生した静電気災害の内, そ の主なものについて報告を求めたところ，78 例に達し， 引火爆発または惔が 68 例, 感電が 10 例である。業 種別々みると，化学工業 38 例，ゴム製品製造業 30 例， パルプ紙加工品製造業 4 例，その他 6 例である。

\section{2. 静電気災害防止対策}

\section{2-1. 静電気対策実施の現況}

1-2.で述べたように多くの事業場において種々の静 電気による災障害危険を生じている。したがって各事業 場に执いても，それぞれの立場から種々の対策を講じて いる。それを調查した結果の概要を示せば次のと初りで ある。

\section{2-1-1. 実施している静電気対策の種類}

300 事業場の内 275 事業場すなわち約 $92 \%$ の事業場 が何らかの対策を実施して扮り，その総件数は $586 て ゙ ，$ その内訳を示せば次のと㧍りである。
接地 $36.8 \%$

除電器の使用

コロナ式 $17.2 \%$

自己放電式

$5.3 \%$

ラジオアイソトープ（R I ) 式

$0.5 \%$

湿度の增加措置

$16.6 \%$

導電性材料の使用

$11.4 \%$

除電剂の使用（塗布または浸漬）

$6.2 \%$

その他

$6.0 \%$

\section{2-1-2. 静電気対策を講じていない場合の理由}

前記 363 事業場のうち，静電気対策を全然講じてい ない事業場が 27，一部講じていないのが 139，無回答 が 63 であるが，静電気対策を講じていない場合の理由 について回答のあったのは189で, その内訳は次のとお りである。

電撃，引火，爆発，火災などの災害の心配がないから

生産障害の影響が注とんどないからー36.5\%

有効な対策がわからないから $11.1 \%$

対策に費用がかかりすざるから $3.2 \%$

対策を講じたがあまり効果がないから $5.3 \%$ その他

$10.0 \%$

\section{2-1-3. 静電気対策実施の効果}

2-1-1. 亿示寸ように種々の静電気対策を実施してい るが，その効果はどうであったかを調査したところ， 298 の回答があり，その内訳は次のとおりである。

非常に有効である $43.3 \%$

かなり有効果であるが十分ではない

$43.6 \%$

ほとんぎ有効でない

$4.4 \%$

わからない

$8.7 \%$

すなわち，非常に有効就よびかなり有効であるとして いるのは，あわせて $86.9 \%$ になって扣り，大部分は满 じた対策の有效性を認めている。

\section{2-1-4. 現場における静電気の測定状況}

有効な静電気対策を実施するためには，現場にお护る 静電気の発生状沉を的確汇性あくすることがきわめて大 切である。そこで前述の 363 事業場に対し，静電気の測 定状況を調査した結果は次のと拈りである。

a. 測定の有無（回答数 288 の内訳）

測定器をもっていて，ときどき測定している

$40.6 \%$

測定器はもっていないが，測定してもらった

ことがある

测定したことが涼い

b. 使用した測定器の種類 (回答数 184 の内訳)

電子管式電位計（集電式電位計, 静電場测定

器など)

$54.9 \%$

静電電圧計

$33.7 \%$

振動容量型電位計 
その他

c. 測定した場合のひん度（回答数 206 の内訳）

定期的に测定

$17.0 \%$

災害または障害の発生しそうな場合に測定

$52.9 \%$

その他

$30.1 \%$

d. 測定しない場合の理由（回答 151 事業場）

測定器がないから

$31.8 \%$

測定方法がわからないから

$14.6 \%$

測定する必要がないから

$37.7 \%$

その他

$10.9 \%$

\section{2-2. 静電気災害防止対笨の要点}

静電気狄害防止対策の基本的な考光方の要点を示せば 次のと㧍りである。

\section{2-2-1. 静電気の発生の抑制}

\section{a. 摩擦の抑制}

液体または粉体などの流動速度を抑制し，また流動過 程中のスクリーン，口紙，ふるいなどの障害物を少なく するなど，接触分離（いわゆる摩擦）を少なくする方法 を採用する。

\section{b. 摩摖部枋についての検討}

静電気の発生量は接触分離する相互の材質抢よびその 表面の状沉によって異なる。带電列も一つの目安にはな るが，現実には実験的に带電量の少なくなるようなもの を選定することが望ましい。

\section{2-2-2. 導体部分の帯電除去}

静電気の芇電は, 静電気の発生之漏洩との関係によっ て定まる。したがって漏洩を図ることが望ましい。

\section{a. 導体部分の接続接地}

i）作業工程または誘導現象によって带電する拈それ のある導体部分は，すべて確実に接続接地する。

ii）接地抵抗は，単倩静電気除去のみを目的とすると きは，108 $\Omega$ 以下でよいが，電気設備の機体の保護接地 または避雷用の接地と併用する場合は これに適する接 地方法および接地抵抗值を採用しテ汸机ばならない。

\section{b. 移動容器または装置類の接地}

i）導電性床および導電性タイヤなどを通じて自動的 に接地されるようにすることが望なしい。

ii）適当な接地用導線と接続金物（たと点ばひっが 形さし込接続器）を用いて，爆発危険の少ない場所で接 続して接地する。また接地用りールを使用することが望 ましい。

\section{c. 回転部分の接地}

回転部分の接地抵抗を検討し，必要ならば尊電性の潤 滑油または摺動ブラシなどを使用する。

\section{b. ゴムホースのノズルなどの接地}

ゴムホースやビニルホースのノズルや接続金物が絶縁 されていて事故を起こすことが多い。導電性のホースを 使用するか，なたは針金入のしかもリード付のホースを
使用し，そのリードを金具に接続して接地して置くこと が必要である。

\section{2-2-3. 不導体への導電性付与}

a. プラスチック類

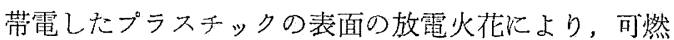
性ガスに着火することが明らかにされている。したがっ てプラスチック類の带電を防止するために適当な除電剂 を混入して成形したり，表面㳊布して処理することが 望ましい。

\section{b. 合成繊維類}

適当な除電剂で処理する。

\section{c. ゴム類}

導電性ゴムとして絶縁抵抗が低く，乙か子経年変化の， 少ない安定したものを使用する。

\section{d. 絶縁性液体類}

石油などで絶縁抵抗の高い液体には適当な除電剤を添 加して絶縁抵抗を低下させる。

\section{2-2-4. 空気湿度の增加による導電性付与}

空気の相対湿度を上げて物体の表面抵抗を低下させる ために，調湿装置や櫴蓩ノズルを使用したり，床面消敞 水することなどが考觉られる。しかし，はっ水性のある 表面には効果が少ない。

\section{2-2-5. 空気のイオン化による除電}

帯電体付近の空気を電嚁して，近極性の電荷を付着さ せこ礼を中和することによって除電することが考光ら れる。

\section{a. 自己放電式}

接地した細線，金属モール，金属ブラシ類を带電体に 近接させ，带電体自体を利用して自己放電させる方式 で，電荷密度の大きいときは，比較的有効である。

\section{b. 交流放電式除電器}

多数の針端突起を有する電極に交流の高電圧を印加乙 て正負雨極性のイオンを発生させ，帯電している電荷の 極性に応じ，いずれかのイオンを堅択的に使用させる力 式である。電源に一般には 5 10kV の商用周波数の交 流を使用し，電極との間は絶縁物を介して容量結合して 電流を制限し，電撃危険のないようにしなければならな い。優秀な除電効果を有するるのができているが，引火 危険のある場所での使用に際しては，実験その他により 放電による着火の危険のないことを慎重に確認しなけれ ばならない。

\section{c. ラジオアイソトープ (RI) 式除電器}

空気の電離に $\alpha$ 線または $\beta$ 線を利用すると，引火 爆発の危険がないので，爆発危険のある場所での使用に 適するが，遮爾法に注意しなければならない。当所に おいてもビニルシートについて基礎的資料を得るととる に特に粉体の除電について優秀な成果を収めている。乙 かし一般にコロナ式に比し除電効辣が低いし，イオンの 
再結合についても考慮しなければならないので, 実用化 についてはさらに十分な研究が必要である。

\section{2-2-5. 人体の帯電除去}

人体は静電気的には一種の導体であるので, 引火爆発 危険のある場所で作業する場合には，作業者の带電を防 止するために，次の点に注意しなければならない。

\section{a. はきもの}

導電性ゴム底を使用したはきものを着用させる。なお 低圧電気設備による感電事故を防止することもあわぬ考 之て，一般にはきものの対地絶縁抵抗が $10^{4} \sim 10^{5} \Omega$ 程度 のものを静電気用の靴として使用することが望ましい。 また靴下によっても抵抗が増加するので，電撃危険のな いメガー（たとえば乾電池式オートメガーで短絡電流が $1.0 \mathrm{~mA}$ 以下のもの）を使用して人体の対地抵抗を測定 することが望ましい。

\section{b. 作業床}

リノリュームその他の絶縁性の材料を避けるとと女 に，木材，コンクリートなどの場合にも，ときどき測定 して点検し, 必要に応じ散水その他の処置を講挎る。

\section{c. 作業衣}

作業衣は木綿または十分に除電処理した化瀻を使用す る。肌衣については人体の電荷が導電性のはきものを通
して直ちに漏洩し，表面に木綿の作業衣を着用している 場合にはあまり実害のない場合が多いが，ときどき測定 してみることが必要である。

\section{交献}

1) 工場事業場に抬ける静電気の奏意調查結果(防爆課)

2) タンクローリー給油時の静電気㷋害とその刘策（坂 主勝弘)

3）ラジオアイソトープによる静電気の带電除去（田中 隆二)

以上産業安全斫究協会参考凟料 No. 2. 1996亿集録 （閣係硎究報告, 労働省産業安全研究所報, No. 1 (1961), No. 2 (1962), No. 1 (1963), No. 1 (1965)

4) 上月三郎, 坂生勝弘, 田中隆二: 放射性同値元素飞 よる静電気の除去についての研究 第 3 報 粉体带 電の除去, 安研所報, No. 3 (1996)

5）上月三郎，坂生勝弘：スパウトに括放粉体の带電 現象，安研所報，No. 3 (1961)

6) 上月三郎：粉体の带電，火㷋，17，No. 4 (1958)

7) N. Gibson: Incendivity of discharge from electrostatically charged plastis, Brit. J. Appl. Phys., 16 (1965)

\section{研究論文集「高分子化学」内容紹介}

\section{第 23 巻・第 259 号・ 1966}

[物理]

[115]ナイロン6の結晶性に与方分子量の影響．．．．．．．．．．．上田伸夫．温品恭彦

[116] ビスフェノールのシアノエチル化合物よりポリアミドの合成

第 9 報 主鎖に $p$-フェニレンオキシ基をもった二三のポリアミドの物性・・・安東忠直・片岡清一

[117] 高分子結晶の外力による微小変形

第 1 報 分子鎖方向の伸張に伴うポリエチンン結晶の微小変形．．．．．．宮坂啓象・牧島邦夫 [基碟工学]

[118]プラスチックの劣化に及注す顔料の影響

第 5 報 ポリカーボーネート樹脂の熱分解・.．．．．．．．．高橋武光・鈴木健一・阿部盛旺

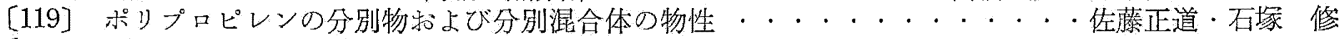

[120] ポリアミド瀻維の延伸について

第 7 報 膨潤による直径变化の配向依存性．．．．．．．．．．．．．．．．高木康夫

[121] ナイロン 6 繊維の熱処理と染色性の関係．．．．．．．．．．．．．．．高木康夫

[化学]

[122]イオンの高周波振動によるポリマーの解重合

第 4 報 解重合物の濁度, 重合度分布…………福富 匹・加倉井敏夫 ·野口達弥

[123] 機械的分裂反忘の速度式について．．．．．．．．．..．．．後藤邦夫．藤原秀樹

[124] 結晶性ポリステンンの構造と物性に関する研究

第 1 報 アイソタクチックポリスチレンの結晶珄について・・・・辻 和一郎・北丸竜三・阪口文雄

〔125] 長鎖アルキルならびにアルキルベンゼンスルホン酸による高分子エステルの加水分解

…………………桜田一郎・坂口康義・大村恭弘

〔126〜127]高分子スルホン酸触媒によるエステルのケン化反応

第7 報 アミノ安息香酸エチルのケン化反応に対する触某効果に及ぼすポリスチレン

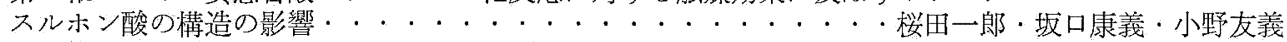

第 8 報 ポリビニルブチラールスルホン酸によるアントラニル酸エチルのケン化反応

[128] ポリビニルアルュールの溶液中でのアセタール化速度に及淁す各種の塩の影響

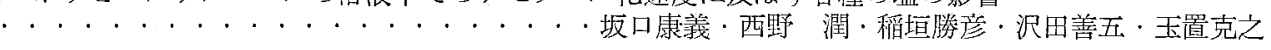

